\title{
THE EQUITABLE JESUS \\ (Jesus' Ministries dealing with Injustice Issues in His Community Context)
}

By: Bakhoh Jatmiko, M.Th. ${ }^{1}$

\begin{abstract}
Textual studies from the Gospel and its historical background reveal that Jesus both, preached forgiveness of sins and provided solutions for the actual needs of people He met. Jesus' ministries weren't only for for people's spiritual needs, but also to break the injustice cycle around Him. The work of Jesus in his ministry is a strong reference to His mission that

He came not only to bring people to heaven but also to present heaven to the earth.
\end{abstract}

Keywords : Jesus, ministry (ies), community, needs, injustice, world

\section{Injustice Issues in Jesus' Context}

\section{Human Rights Issue}

Israel's History is filled with it's nation struggle to have their independence from some colonizer nations. There is a fact that for thousands of years, with just only brief periods of independence the Jewish people were primarily subject to foreign rule like Egyptian, Syrian, Babylonian, Persian, Greek, Roman, etc. Rome's involvement in the Eastern Mediterranean dated from $63 \mathrm{BC}$, following the end of the Third Mithridatic War, when Rome made Syria a province. After the defeat of Mithridates VI of Pontus, the proconsul Pompeius Magnus (Pompey the Great) remained to secure the area, including a visit to the Jerusalem Temple. During the 1st century BC, the Herodian Kingdom was established as a Roman client kingdom and in $6 \mathrm{AD}$ parts became a province of the Roman Empire, named Iudaea Province. ${ }^{2}$

For the ordinary people of the Jewish homeland, Rome was a kind of dominant political factor. In the hierarchy of power, the Jewish self-government reported to the authority of the local Roman government (King Herod), which reported to Rome (Emperor Caesar). The Roman government required heavy taxation of its people. Tax collectors were local employees considered to be outcasts and traitors. The Jews held much distrust and often hatred for the Roman Empire - they were unwilling subjects. Romans domination made Jewish people had to submit to Romans authority. Bible records that at the time of Jesus' birth, the local Roman ruler, King Herod had initiated a massacre of all Jewish baby boys born at the time.

\section{Gender Issues}

By the time of Christ, the role of women had drastically changed for the worse compared to earlier times of Israel. In the earlier time women participated in every aspect of community life except the Temple priesthood. Women were included when God instituted

\footnotetext{
${ }^{1}$ Bakahoh Jatmiko is a lecture in Indonesia Nazarene Theological college teaching New Testamment Subject. He is an Adademic Dean in the same Theological college.

${ }^{2}$ Benjamin Isaac, The Near East under Roman Rule: Selected Papers (Leiden: Brill 1998).
} 
the Mosaic covenant (Deut. 29:11), and were present when Joshua read the Torah to Israel. Their presence was not just an option; they were required to be present for the public reading of the Scriptures on the Feast of Tabernacles (Deut. 31:12). Women freely engaged in commerce and real estate (Prov. 31), as well as in manual labor (Ex. 35:25; Ruth 2:7; 1 Sam. $8: 13)$.

In the first century, women were considered second-class citizens, akin to slaves. The fact that they are mentioned as followers of Jesus is unusual - both that they would be allowed to follow him with his disciples, and unusual that the authors of Jesus' biographies would mention their presence at all. In Talmudic times, respectable women were expected to stay within the confines of the home. The terminology for a prostitute was "one who goes abroad." The woman of the first century did not even do her own shopping, except possibly to go out, accompanied by a slave, to buy material which she would use to construct her own clothing at home! Bereishit Rabbah 18: 1 says that if a woman was ever in the streets, she was to be heavily veiled and was prohibited from conversing with men. ${ }^{3}$

Women were not educated at that time. Based on the passage in Deut. 4:9, "teach them to thy sons," R. Yose b. Akiva has some commands by adding stattement : "your sons, but not your daughters;" Indeed, R. Eli'ezer says: "Whoever teachs his daughter Torah is considered as if he taught her foolishness." The few rights of a woman included her right to go to the House of Study to hear a sermon or pray and it was also her basic right to attend a wedding feast or a house of mourning, or to visit her relatives. ${ }^{5}$

Women were separated from men in private, public and religious life. They could go to the Temple, but could not venture beyond the confines of the Women's Court (there was no such court found in the Biblical descriptions of Solomon's Temple). Women were not allowed to participate in public prayer at the Temple, although they were encouraged to have private prayer lives at home.

\section{Racial Issues}

The Jews understood that the world to be divided into two types of people using term : Jewish and Gentile (non-Jew). The Jews worked hard to disassociate themselves from the Gentiles, even they have some relation with Gentiles in some paticular basis. ${ }^{6}$ Jewish identified theirself with two main stages, namely ethnic and ideological. ${ }^{78}$ Jewish identify themself as the family of Abraham, Isaac and Jacob became the tribe, then the people, defined by three factors - genealogical (who am I descended from?), geographical (where do

\footnotetext{
${ }^{3}$ Bereshith Rabbah (The Great Genesis) is a midrash comprising a collection of rabbinical homiletical interpretations of the Book of Genesis. It contains many simple explanations of words and sentences, often in Aramaic, suitable for the instruction of youth. It also contains varied haggadic expositions popular in the public lectures of the synagogues and schools. The tradition that Rabbi Hoshaiah is the author of Genesis Rabbah may be taken to mean that he began the work as numerous additions have been made over the subsequent years before it was redacted (4th-5th Century CE). https://www.sefaria.org/The William Davidson Talmud/Bereishit Rabbah 18: 1

${ }^{4}$ https://www.sefaria.org/ The William Davidson Talmud/Mishnah Sotah 3: 4, accessed August 21, 2017

${ }^{5}$ https://www.sefaria.org/ The William Davidson Talmud/Vayikra Rabbah, Sotah 22a, Mishnah Ketubot 7:5, accessed August 21, 2017

${ }^{6}$ Warner J. Cahnman, Jews and Gentiles : A Historical Sociology of Their Relations, ed. Judith T.

Marcus, Zoltan Tarr (New Brunswick, New Jersey : Transaction Publishers, 2004), p.1-9.

${ }^{7}$ Warner J. Cahnman, Social Issues, Geopolitics, and Judaica (New Brunswick, New Jersey : Transaction Publishers, 2004), p73-80.

${ }^{8}$ Lawrence J. Epstein, The Basic Beliefs of Judaism: A Twenty-first-Century Guide to a Timeless Tradition (10 Thornbury Road, Plymouth, 2013: Jason Aronson), p82,114
} 
I live?) and historical (what events have moulded my history?). ${ }^{9}$ The ethos of the family/tribe/people was now delineated - there was a God, one, invisible and indivisible, who created the world and continued to protect it; He chose the family of Abraham as the ones to carry His torch throughout history.

The term "gentile" (from "gens", a race or ethnic group) was not used as such at this period. Much later it became common among Jews to call an outsider a goy (plural : goyim). ${ }^{10}$ There is a cleavage of identity was between Israelites and goy nation that known as idolaters. Originally, Jewish people did not deal with any nations because of theological reason. Jews and gentiles living in amity and looking at one another with hostility and suspicion. Jews had a low opinion of gentile law courts (though the gentile law of the land was the law other than in spiritual matters). There are three famous rabbinic sayings to express Jewish opinion to other nations as explained by Maier :

Taut ba'goyim mutar - A mistake with Gentiles is allowed, namely, somene who cheats a Christian is not a sinner. Tov she'bagoyim harog - one must kill the besy among the Gentiles. Tov she'ba'nehashim rotzetz et moho - One must crush the brains ofthe finnest sanke, an expression that demonstrares that Jews equate the Christian with serpents. ${ }^{11}$

There is also a chance for gentile to be part of Jewish fold. Some were resident aliens (gerei toshav) who resided in a Jewish milieu, sometimes marrying a Jew, sometimes living as slaves in a Jewish household and becoming part of the family in the narrower and the wider sense, and adopting Jewish practices. ${ }^{12}$ Outsiders regularly attached themselves to the Jewish people in this way.

\section{Poverty}

The economy of first century Israel societies was agrarian sicieties. It is mean that the economic backbonde of this societies was agriculture. ${ }^{13}$ The agriculture area was supported by three key segments: agriculture of olives, figs, grains, dates, and vineyards. Trade fostered by Israel's key location on the Mediterranean Sea; and large government building projects sponsored by King Herod. King Herod employed many laborers by commissioning many public works (e.g. building temple in Jerusalem, palaces, ports, fortresses, stadiums, ornate stone carvings, etc.). There was a very large disparity between rich and poor. The upper class was made up of the temple priests and priestly aristocracy (including the Sadducees - a Jewish sect). The middle class was comprised of traders and merchants, artisans (stonecutters, masons, sculptors) and craftsman (metal, wood, cloth dye). The Pharisees (another Jewish sect), sages, scribes, and teachers were also a part of the middle class. The lower class was made of laborers (weavers, stone carriers, slaves (non-Jewish person taken into slavery because of debt), and the unemployable (lepers, blind, insane, crippled, etc.).

${ }^{9}$ Tet-Lim N. Yee, Jews, Gentiles and Ethnic Reconciliation: Paul's Jewish identity and Ephesians (Cambridge: Cambridge University Press, 2005), p73-110.

${ }^{10}$ Epstein, The Basic Beliefs of Judaism, p182.

${ }^{11}$ Yaacov Deutsch, Judaism in Christian Eyes : Ethnographic Descriptions of Jews and Judaism in Early Modern Europe, trans. Avi Aronsky (198 Madison Avenue, New York, 2012), p193

${ }^{12}$ Frederick S. Roden, Recovering Jewishness: Modern Identities Reclaimed (Santa Barbara, California: Praeger, 2016), p185-192

${ }^{13}$ G. E. M. De Ste. Croix, The Class Struggle in the Ancient Greek Work (Ithaca, NY: Cornell University, 1981), p210-211. 
Jesus himself mentioned about hunger, thirst and naked in His teaching (Mat. 25: 35-36). It represents the conditions that were happening in Jesus' day.

In other scriptures, the Gospel mentions about baggars, poor and cripples. In Greek text, the word for "poor" is ptōchos, that means someone who is destitude. ${ }^{14}$ Another word for "pood" in Greek is penēs, where this word means a person who must earn his living by his own unremitting toil. Jesus mentioned the word ptōchos in several verses. When John the Baptist's pupils came to Jesus and aksed about him, Jesus claimed that He came to help the weak and to preach the good news for the destitute (Mat. 11:5). When a man ran up to Jesus and asked how to inherit eternal life and Jesus replied to go and sell everything and give the money to the destitute (Mrk. 10: 21). Another story came when Jesus sat facing the offering box while many rich people were dropping in large amounts, a destitute widow came and dropped in two small copper coins, worth about a cent (Mrk. 12:41). This story is a real condition that were happened in Jesus context.

In the Gospel, beggars, poor and cripples are viewed in the same group of the weak. The "poor" are mentioned in the same breath with the sick in the earliest Jesus tradition (Mrk. 11: 2-5); and though "poverty" is synonimous with hunger and lamentation (Lk. 6:20). This group is not necesarally beggars in the strict sense, that is persons that economically completely depend on help from others. ${ }^{15}$ As recorded in the Gospel, there were in many occasion that this group appear in Jesus ministry. Friedlander in Schottfoff gives conclude that the poverty is widespread throughout the Roman empire; even in imperial Rome itself, despite a well-organized public system of grain distribution. ${ }^{16}$

\section{Believe Systems Conflict}

Judaism in the first century was not a state religion. Jewish believe system recognize herarchy and rank. There was a diversity in Judaism in that period. Judaism is not a monolithic religious or cultural entity at this time. There were some different groups, such the Pharisees, were a school of interpretation of Biblical text. The Pharisee party emerged largely out of the group of scribes and sages. Their name comes from the Hebrew and Aramaic parush or parushi, which means "one who is separated." It may refer to their separation from Gentiles, sources of ritual impurity or from irreligious Jews. ${ }^{17}$ The separation, according to Schiffman, "is most probably referring to their separation from levitically impure food and from the tables of the Am-ha-ares, the common people, who were not scrupulous regarding the laws of levitical purity or tithes. ${ }^{18}$

Their opponents were the Sadducees, who were no less pious than the Pharisees, but the Sadducees did not believe in the authoritative nature of the ancestral laws. Josephus relates that the Sadducees reflected the 'traditions of the Fathers,' which seems to have been the forerunner of the oral law, and was also observed as law by the Pharisees. ${ }^{19}$ Sadducees are usually associated with aristocratic Priests, therefore they are in Jerusalem. Most of them were apparently priests or those who had intermarried with the high priestly families. ${ }^{20}$ They

\footnotetext{
${ }^{14}$ Luise Schottfoff, Wolfgang Stegemann, Jesus and the Poor, trans. Matthew J. O'Connell (Eugene, Oregon : WIPF and Stock Publishers, 1986), p16.

${ }^{15}$ Ibid

${ }^{16}$ Ibid

${ }^{17}$ Shaye J. D Cohen, From the Maccabees to the Mishnah (Louisville, Kentuky: The Westminster Press, 1987), p159

${ }^{18}$ Lawrence H. Schiffman, Reclaiming the Dead Sea Scrolls (New York: Vintage Books, Random House, Inc. 1993), p13.

${ }^{19}$ Schiffman, Reclaiming the Dead Sea Scrolls, p13

${ }^{20}$ Rachael Jospe and Wagner, Great Schisms in Jewish History (New York: Ktav Publishing House, Inc., 1984), p12
} 
seem to not have thought that there was resurrection of the dead, which by this period is almost a normative belief in Judaism. They denied the notions of reward and punishment after death and the immortality of the soul. ${ }^{21}$

Essenes were another group of people very concerned with purity. There is a lot of purity ritual associated with them. Josephus and another first century historian and writer, Philo, talk about the Essenes as being a philosophic community with communal property. There was a group within the Essenes who were celibate. ${ }^{22}$

The other big group in Judasim was Insurrectionists. They were a group of people the rebelliousness and weariness with Rome that ultimately led to the Great War against Rome in 66 to 70, eventuating in the destruction of the Temple. It's believe that many other Jewish sects were existed during the Second Temple period. ${ }^{23}$

Among those groups, conflicts between Pharisees and Sadducees were often happened than conflict between other groups. The conflicts took place in the context of much broader and longstanding social and religious conflicts among Jews, dating back to the time of slavery in Egypt and exacerbated by the Roman conquest. ${ }^{24}$ Another conflict was cultural, between those who favored Hellenization (the Sadducees) and those who resisted it (the Pharisees). A third was juridico-religious, between those who emphasized the importance of the Second Temple with its rites and services, and those who emphasized the importance of other Mosaic Laws. A fourth point of conflict, specifically religious, involved different interpretations of the Torah and how to apply it to current Jewish life, with Sadducees recognizing only the Written Torah (with Greek philosophy) and rejecting doctrines such as the Oral Torah, the Prophets, the Writings, and the resurrection of the dead.

The Jewish historian, Josephus, has a very memorable line.

He says, "one temple, for the one God." The Jews saw themselves as a unique people, with the one God alone... there's one God of this one special people, one temple, and that's a very powerful idea, reflecting accurately, I think, the historical truth that the temple was a very powerful unifying source, within the Jewish community. At the same time, the temple also serves as a source of division and a source of conflict in the Jewish community. ${ }^{25}$

It is interesting thing about the temple in the days of Jesus, on the one hand, it's a grand, new place. It's the center of life and worship. It's the showpiece of Jewish tradition. And yet, it could also be a center of controversy and tension.

\section{Slavery and Human Traficking}

The Bible contains several references to slavery, which was a common practice in ancient time in ancient Near East and it's practice was found in New Testament period. By this fact, it is not surprising to read some verses in the Bible stipulates the treatment of slaves both in the Old Testament ${ }^{26}$ and New Testament. ${ }^{27}$

\footnotetext{
${ }^{21}$ Schiffman, Reclaiming the Dead Sea Scrolls, p74

${ }^{22}$ Cohen., From the Maccabees to the Mishnah, p159.

${ }^{23}$ Lawrence H. Schiffman, Sectarian Law in the Dead Sea Scrolls: Courts, Testimony and the Penal Cede (Chico, CA: Scholars Press, 1983), p1.

${ }^{24}$ http://www.Jewishvirtuallibrary.org, accessed August 21, 2017

${ }^{25}$ E. J. Brill, Leiden, Josephus, the Bible and History, edited by Louis H. Feldman,Gåohei Hata (Tokyo : Yamamoto Shoten Publishing House, 1993), p202

${ }^{26}$ Exodus 21:2-6; Leviticus 25:39-55; Deuteronomy 15:12-18

${ }^{27}$ Ephesians 6:5; I Timothy 6:1
} 
Slavery can be happen by several causes. It was possible to be born into slavery. If a male Israelite slave had been given a wife by his owner, then the wife and any children which had resulted from the union would remain the property of his former owner, according to the Exodus 21:1-4. Although no nationality is specified, 18th century theologians John Gill (1697-1771) and Adam Clarke suggested this referred only to Canaanite concubines. ${ }^{2829}$

Second category as a reason someone become slave is poverty, and more general lack of economic security, compelled some people to enter debt bondage. In the ancient Near East, wives and (non-adult) children were often viewed as property and were sometimes sold into slavery by the husband or father for financial reasons. Children of a deceased debtor may be forced into slavery to pay off outstanding debts; similarly, it is evident that debtors could be forced to sell their children into slavery to pay the creditors. It is understood by Jewish and Christian commentators that this referred to the sale of a daughter. This practice is also considered as sexual slavery, or being sold to be a wife, was common in the ancient world. ${ }^{30}$ Throughout the Old Testament, the taking of multiple wives is recorded many times.

Enslavement concept had been a common idea in Israel for centuries. Jesus and New Testament writers gave comment or brought the concept into their teaching. Jesus Indentifed Himself as servant (doulos). ${ }^{31}$ The well known parable of Jesus in Mathew 25 tells story about master and his servants. In Mathew 8 there is story about a humble centurion of Capernaum pleaded Jesus to heal His servant. Form several stories in the Gospel, it is believed that concept and practice of slavery were exist in Jesus time.

\section{Children Abuse Issues}

Historical and exegetical studies to the children issue in the early centuries will expose the dramatic fact how children treated by that time. Infancide, out casting children, homeless children and neglecting children were common practice in the first century during Greek and Roman world. The normal method of birth control in the Greek and Roman world was infanticide. Contraception was uncertain, and abortions were dangerous, so it as normal to let an unwanted pregnancy come to term and then dispose of the baby. his was especially common for any deformed, weak, illegitimate or unwanted infants, such as girls who were an economic liability. The motives for this were mainly inancial - the poor could not afford to bring up too many children, and the rich dd not want to ivide up their estates among too many children. Caesar Augustus exposed his grand daughter Julia's illegitimate child and he was, for most Romans, the highest model of moral rectitude. ${ }^{32}$

\footnotetext{
${ }^{28} \mathrm{http}: / /$ www.ewordtoday.com/exodus, accessed August 21, 2017

${ }^{29} \mathrm{http}: / /$ www.godrules.net/library, accessed August 21, 2017

${ }^{30}$ Gn. 25:1; cf. 1Ch. 1:32; Gn. 30:4; 31:17; cf. Gn. 35:22; 2Sam. 12:11; cf. 2Sam. 20:3

${ }^{31}$ Mark 10:45

32 Suetonius, The Twelve CaesarsII. 65: "He would not allow the child born to his randdaughter Julia after her sentence to be recognized or reared". Soon after birth, the father or head of the household) had to recognise the baby and agree to raise it, and if he did not do o, it had to be discarded by killing it or exposing it. See also Cicero, Letters to Atticus11.9 here Evelyn Shuckburgh translates "would that I had never been born", she notes that the iteral Latin reads "would that I had never been taken up" - referring to the ceremony of ecognition when the father traditionally picked the infant off the floor. See Cicero: The etters. he whole extant correspondence in chronological order, translated into English, trans. by E. S. huckburgh, (4 vols, London,
} 1900-05). 
A papyrus letter (P.Oxy 4.744) written in 1 B.C.E. that was found at the Oxyrhynchus site in Egypt shows how the baby's life was rested rested in the father's (or head of the household's) hands. ${ }^{33}$

A letter dated 29th year of the Emperor Augustus, 23rd day of the Egyptian month Pauni (17th June 1 B.C.E.), from Hilarion to his pregnant wife Alis. The overall tone of the letter is very tender. Hilarion is away in Alexandria. He reassures Alis that he is thinking of her and that she should not worry. Although he has not yet received his pay, he assures her that as soon as he does, he will send it up to her. However he also gives her this instruction concerning the unborn baby: "Above all, if you bear a child and it is male, let it [live], but if it is female, cast it out."

The word here for 'cast it out' ("丷к $\beta \alpha \lambda \varepsilon$ ) is the same word used in the Gospels to describe Jesus expelling (casting out) demons. Within the patriarchal structure of antiquity, the ultimate decision of whether a baby should live or die rested in the father's (or head of the household's) hands.

Matthew has reported in the Gospel that Herod the Great to maintain his geopolitical power pracriced terible thing of massacring children. The Excavations of neo-natal body dumps in Late Roman Period Israel have shown that infanticide was fairly common. Research of such a dump in the sewer system under a Roman bathhouse in Ashkelon and comprising the skeletal remains of about 100 babies (up to approximately 3 months old) suggests that 'unwelcome' or 'inconvenient' babies that were the result of extra-marital relationships were (literally?) cast away. Moreover, infanticide appears to have been viewed as the favoured means of family planning allowing sex selection and birth order to take place (see: $\mathrm{M}$. Faerman et al. 1998).

The Gospels reports first century community often ostracized the children. Mark 10:13-16 is an example of first century view on children. Street children were to be found among them. It is striking that, in many places in Matthew, the "crowd" is called the "least" (Mt 25:40,45), the "children" (Mt 15:26; 18:3), the "little ones" (Mt 18:14), and "sheep" (Mt 18:12; cf. Mt 10:36 and 15:26). The metaphorical use of "sheep" in Matthew 9:36 and 18:12 correlates with the expressions "the lost sheep of Israel" in Matthew 10:6 and "the little children" in Matthew 18:3-5, as well as with "the little ones" in Matthew 18:6, 10, 14 (cf. Mt 10:42).

\section{Justice According to Jesus}

In those kind of situation mentioned previously, the mission and message of Jesus is pretty clearly summarized in Luke 4:18-19. This is an "inaugural sermon" of a programmatic statement of Jesus to give a good news statement for the poor. ${ }^{34}$ "He wants to give sight to the blind, liberty to the captives, and deliverance to the oppressed." In this passage, Jesus mentioned about His duty to bring justice and deliverance to the community He dealt with. In the gospel, readers can find the justice values were expressed in Jesus ministries.

\footnotetext{
${ }^{33}$ https://bibleresearchtoday.com/The Dark Reality of Infanticide Behind Matthew 1:21, accessed on August 21, 2017

${ }^{34}$ Schottfoff and Stegemann, Jesus and the Poor, p90
} 


\section{Equallity and Opportunity for All}

This first value can be found in Jesus ministries dealing with gender issues, especially in the state of woman in Jewish tradition. The Gospel shows that Jesus consistently treated women and men as equals. He violated numerous Jewish traditions and regulations from Talmudic era, which specified gender inequality. There are many stories in the Gospel how Jesus treated woman with dramatic difference than the three main Jewish religious groups of the day: the Essens, Pharisees and Sadducees. Mark 5: 25-34 describes that Jesus cured of a woman who suffered from menstrual bleeding for 12 years. In Jewish tradition, this kind of woman was unclean in ceremonial law. It was forbidden to touch or to be touched by unclean one.

John 4:7 to 5:30 describes Jesus' conversation with a woman of Samaria. She was doubly ritually unclean since she was both a foreigner and a woman. In Judean society of the day, it was a major transgression for a man to talk to a woman other than his wife, children or within their own families. Jesus also helped a Canaanite woman, another foreigner, in Matthew 15:22-28. Although he described non-Jews as "dogs", he was willing to talk to her, and is recorded as having cured her daughter of demon-possession.

In Luke 10:38-42 readers can find some women's names in that passage. It is interesting because from that passage there is a fact that some of Jesus' disciples were women. What Jesus did was restricted at that time. Jewish tradition was to not allow women to be taught.

Jesus expressed concern about women's needs as a man had. In Jesus' time widow was categorized as a weak group. Jesus repeated the importance of supporting widows throughout his ministry. The Gospel of Luke alone contains 6 references to widows: (Luke $2: 36,4: 26,7: 11,18: 1,20: 47$ and 21:1). The equality of Jesus treatment also showed in the terminology He used referred to a woman. Luke 13:16 describes how he cured a woman from an indwelling Satanic spirit. He called her a daughter of Abraham, thus implying that she had equal status with sons of Abraham. "The expression 'son of Abraham' was commonly used to respectfully refer to a Jew, but 'daughter of Abraham', was an unknown parallel phrase... It occurs nowhere else in the Bible.'It seems to be a designation created by Jesus.

\section{The Same Value for All}

The Bible contains more than 300 verses on the poor, social justice, and God's deep concern for both. In Jesus, God came as a poor man, lived as a poor man, and died as a poor man. He is a good news to the poor. And as such, Jesus cared deeply about the impoverished. Jesus shattered this darkness by offering his teachings freely to anyone who would listen. Jesus proclaimed that one of His duties in this earth is bringing good news (Gospel) to the poor.

He came to Nazareth, where He had been brought up; and as was His custom, He entered the synagogue on the Sabbath, and stood up to read. ". . . The Spirit of the LORD is upon $\mathrm{Me}$, because $\mathrm{He}$ appointed Me to preach the gospel to the poor. He has sent Me to proclaim release to the captives, and recovery of sight to the blind, to set free those who are downtrodden, to proclaim the favorable year of the LORD. Jesus' missions was very clear. He came to care the marginalized groups and break the injustice cycle.

In His teaching, Jesus addressed his disciples: "Blessed are you who are poor, for yours is the kingdom of God. (Luke 6:20)" in this verse He calls the poor "blessed"; in other words, favored by God. In the rest of the blessings and woes of Luke 6:20-26, there is definitely nothing second class about the poor or the weak or the helpless in Jesus eyes. From 
the very beginning of the Gospel of Luke, Jesus is re-presented as associated with the poor and re-presented the cause of God as blessing the poor. ${ }^{35}$ In the parable of the sheep and the goats (Matthew 25:31-46), Jesus taught that whoever helped a brother or sister who was hungry, thirsty, needing clothes, sick, or in prison, "Whatever you did for one of the least of these brothers of mine, you did for me." The poor, who were followers of God, were considered part of his family. Feeding them equaled feeding Jesus.

How Jesus valued the poor also appeared when He taught how His followers treat the poor. Jesus taught that if the followers of Him ever throw a party or banquet, "invite the poor, the crippled, the lame, the blind, and you will be blessed. (Luke 14:13-14)" In every cultures in the world in general, when someone held a party, the guests invited will represent the host honorary. Honorable host will have honorable guests. But in His teaching, Jesus articulate the radical idea of inviting the poor, the crippled, the lame and the blind. Jesus Broke down those socioeconomic barriers and fellowship with the poor and everyone do his command will be divinely favored.

\section{Advocacy for the Weaks}

In John first letter, he explained that sinners have Jesus as an advocate to the Father. The apostle of John in his first letter, explains that Jesus is the advocate for the sinners. ${ }^{36}$ The term translated "advocate" in this verse seems to have its common meaning of sponsor or patron, someone who could influence a court or power person in one's favor. ${ }^{37}$ This verse explains that Jesus is the advocate for human's spiritual needs.

Jesus live which is recorded in the Gospel demonstrated that He is an advocate not only for spiritual needs, but also the social and physical needs of people He met. At Jesus time, children were often neglected and did not value as a mature one. The Gospel recorded the wonderful actions of Jesus how He treated the children. Mar 10:16 : "And he took them up in his arms, put his hands upon them, and blessed them." ${ }^{38}$ It is important in some instances to indicate the symbolic value of an embrace by some type of classifying phrase, for example, "to show his love for by putting his arms around" or "to embrace to show affection." 39 The expression "put his hands (KJV)" is translated from the Greek word tí $\theta$ $\mu$ (tithēmi). It is interesting because the word described Jesus' action dealt with children is antonym for the Greek word ektithemai is used to denote "being put out of the home; left out of doors; abandon." What Jesus did was a great news for children and a contrast with common practice at that time. Jesus' acceptance of the children, should be seen as a condemnation of the practice of "turning the children out of the home."

Helping the poor and needy was indeed a priority for Jesus, and sometimes He helped people whether they believed in Him for eternal life and became His followers or not. Sometimes He helped people just because they needed help. Fixing the world, helping the poor, and defending the oppressed was His job, and the job He passed on to those who follow Him. And fixing what is wrong with the world means looking not just at people's spiritual needs, but also their mental, emotional, psychological, and physical needs as well. Norman,

\footnotetext{
${ }^{35}$ Allen Verhey, Remembering Jesus: Christian Community, Scripture, and the Moral Life (Grand Rapids, Michigan: Wm. B. Eerdmans Publishing, 2005), p278

361 John 2:1, 2, English Standard Version

${ }^{37}$ Paraklhtos, which is not used for Jesus elsewhere in the New Testamment. But, the Gospel recorded many of Jesus advocateship during His ministries. David Rensberger, Abingdon New Testament Commentaries: 1, 2, \& 3 John (Nashville:Abingdon Press, 2011), p56

${ }^{38}$ King James Version

${ }^{39}$ Louw and Nida, Bible Works video demo library, copyright 2012
} 
the 17th century, concluded the work of Jesus to help the weaks with the word "the advocateship" of Jesus; Christ is the advocate of His people and he pleaded the cost of the poor and needy. ${ }^{40}$ The Gospel of Jesus Christ is a Gospel which addresses all of humanity's needs.

\section{Conclusion}

The Incarnation of Jesus Christ is an amazing work of God. Incarnation not only brings implication in spiritual deliverance; but this work also sets the real example for people to transform the world filled with injustice and needs. Jesus Christ has set perfect example how a person who lives in God's will deal with needs in their surrounding.

Jesus' context as pictured in the Bible, filled with problems, awaken His followers that this world always has needs to be answered. The problems in Jesus' community context will always be the problems in the human history. Injustice, poverty, discrimination, abuse, violence and many other social problems will always be present until this earth be purified by God in His day.

The life of Jesus has become an ideal direction how His followers should take an action where there is a need in their community context. The awareness that Jesus not only become the solution for the spiritual problem (sins), makes the believers and His church have the same call for this world; namely, break the injustice cycle, giving the same opportunity for all, same value for all and advocacy for the weak and in need.

${ }^{40}$ Dorman Newman, He Advocateship of Jesus Christ, Clearly Explained, and Largely Improved, for the Benefit of All Believers, Etc. (London: The British Library, 1688), p182. 


\section{BIBLIOGRAPHY}

Cahnman, Warner J. Jews and Gentiles : A Historical Sociology of Their Relations, edited by: Judith T. Marcus and Zoltan Tarr, New Brunswick, New Jersey : Transaction Publishers, 2004.

Cahnman, Warner J. Social Issues, Geopolitics, and Judaica. New Brunswick, New Jersey : Transaction Publishers, 2004.

Cohen, Shaye J. D. From the Maccabees to the Mishnah, Louisville. Kentuky: The Westminster Press, 1987.

Croix, G. E. M. De Ste. The Class Struggle in the Ancient Greek Work. Ithaca, NY: Cornell University, 1981.

Deutsch, Yaacov. Judaism in Christian Eyes : Ethnographic Descriptions of Jews and Judaism in Early Modern Europe, translated by: Avi Aronsky, 198 Madison Avenue, New York, 2012.

Epstein, Lawrence J. The Basic Beliefs of Judaism: A Twenty-first-Century Guide to a Timeless Tradition. 10 Thornbury Road, Plymouth, 2013: Jason Aronson.

Isaac, Benjamin. The Near East under Roman Rule: Selected Papers. Leiden: Brill 1998

Jospe, Rachael and Wagner. Great Schisms in Jewish History. New York: Ktav Publishing House. Inc., 1984.

Leiden, E. J. Brill. Josephus. the Bible and History, edited by Louis H. Feldman. Gåohei Hata .Tokyo : Yamamoto Shoten Publishing House, 1993.

Louw and Nida. Bible Works video demo library, copyright 2012.

Newman, Dorman. He Advocateship of Jesus Christ, Clearly Explained, and Largely Improved, for the Benefit of All Believers, Etc. London: The British Library, 1688.

Rensberger, David. Abingdon New Testament Commentaries: 1, 2. \& 3 John. Nashville: Abingdon Press, 2011.

Roden, Frederick S. Recovering Jewishness: Modern Identities Reclaimed. Santa Barbara. California: Praeger, 2016.

Schiffman, Lawrence H. Sectarian Law in the Dead Sea Scrolls: Courts. Testimony and the Penal Cede. Chico. CA: Scholars Press, 1983. House. Inc, 1993.

Schottfoff, Luise and Wolfgang Stegemann. Jesus and the Poor, translated by: Matthew J. O'Connell .Eugene. Oregon : WIPF and Stock Publishers, 1986.

Verhey, Allen. Remembering Jesus: Christian Community, Scripture, and the Moral Life. Grand Rapids. Michigan: Wm. B. Eerdmans Publishing, 2005.

Yee, Tet-Lim N. Jews. Gentiles and Ethnic Reconciliation: Paul's Jewish identity and Websites Ephesians. Cambridge: Cambridge University Press, 2005

http://www.ewordtoday.com/exodus

http://www.godrules.net/library

http://www.Jewishvirtuallibrary.org

https://bibleresearchtoday.com/The Dark Reality of Infanticide Behind Matthew 1:21

https://www.sefaria.org/ The William Davidson Talmud/Mishnah Sotah 3: 4

https://www.sefaria.org/ The William Davidson Talmud/Vayikra Rabbah. Sotah 22a.

Mishnah Ketubot 7:5.

https://www.sefaria.org/The William Davidson Talmud/Bereishit Rabbah 18: 1 
74 J Jurnal Teologi SANCTUM DOMINE 